\title{
TINKLARAŠČIO MEDIJOS ESMINIAI BRUOŽAI IR PANAUDOJIMO GALIMYBE்S
}

\author{
Daiva Janavičienè \\ Klaipédos universitetas
}

\begin{abstract}
Anotacija
Straipsnyje analizuojami esminiai tinklaraščio medijos bruožai ir jų nulemtos tinklaraščiu panaudojimo galimybès. Taikomi teoriniai indukcijos, dedukcijos, analogijos tyrimo metodai. Gilinamasi ị naujųjų socialinių medijų istoriografiją, identifikuojamos tinklaraščių mokslinio tyrimo sritys, analizuojamos tinklaraščių turinio ypatybès, lyginami apibrěžimai ir klasifikacijos.

PAGRINDINIAI ŽODŽIAI: tinklaraštis, naujosios medijos, socialinès medijos, tinklaraščių bruožai.
\end{abstract}

\begin{abstract}
This article analyse fundamental blog media features and overviews the blog use possibilities. The research is being conducted using theoretical induction, deduction and analogy research methods. Focuses in the short social media history, identified areas of research, analyse blog's content characteristics, blog media definitions and classifications are compared.
\end{abstract}

KEY WORDS: blog, new media, social media, media features.

DOI: http://dx.doi.org/10.15181/tbb.v67i2.854

\section{Ivadas}

Socialinès medijos moderniame pasaulyje užima vis didesnę interneto dalị, tampa svarbia informacijos sklaidos, saviraiškos ir komunikacijos priemone. Socialinès medijos atsirado ir paplito internete ịsigalejus web 2.0 galimybėms, kurios leido supaprastinti dvikryptę komunikaciją. Šio tyrimo tikslas - išanalizavus esminius tinklaraščio medijos bruožus, apžvelgti tinklaraščiu panaudojimo galimybes. Tyrimo objektas - tinklaraščio medija. Tyrimas atliekamas, taikant teorinius indukcijos, dedukcijos, analogijos tyrimo metodus. Analizuojant naujuju socialinių medijų istoriografiją, lyginami tinklaraščio apibrežrimai, apžvelgiamos tinklaraščiu mokslinių tyrimų sritys, pristatomos tinklaraščiu klasifikacijos, apibūdinamos tinklaraščiu medijos savybès, analizuojamos šios medijos panaudojimo galimybès. Daroma išvada, kad esminiai tinklaraščio medijos bruožai (teksto autentiškumas, nesudètinga kompiuterinio programavimo technologija, igalinanti tiesioginę prieigą prie auditorijos ir atgalinị ryši su ja) lemia plačias medijos panaudojimo galimybes. 


\section{Istoriografija}

Mus supančios aplinkos pažinimas vyksta keičiantis informacija. Informacijos perdavimo priemonès arba kanalai, kuriais ji perduodama, vadinami medijomis (lot. media - vidurys). Medijų teorijos yra XX a. antrosios pusès reiškinys, apimantis neilgą istorinį laikotarpị. Anot V. Michelkevičiaus, „medijų peizažas keičiasi greičiau nei teorijos apie jas" (Medijų kultūros balsai, 2009, p. IV). Konkuruojant naujoms technologijoms, kai kurios medijos išnyksta. Tuo tarpu kitos - paplinta ir įsigali. Remiantis daugelio tyrejjų mintimis, socialinès medijos nurodo virtualiose bendruomenėse ar interneto tinkluose vykstančią žmonių tarpusavio sąveiką, kai bendraudami vieni su kitais jie kuria, dalijasi ir keičiasi idejomis bei informacija. D. Craig, analizuodamas interneto žurnalistikos meistriškumą, tinklaraščius išskiria kaip atskirą medijų rūšị. Tinklaraščio kūrejjas tampa ne tik ịvairiomis medijomis pagrịsto teksto kūrejjas, bet ir redaktorius bei leidejjas, kuris turi savarankiškai apsispręsti, kokị turinị atrinkti kaip skelbtiną, apsispręsti dẻl dizaino, teksto ir iliustracijų formatų, paskelbti informaciją viešai prieigai (Craig, 2010, p. 25-53).

L. Nevinskaitè (2011, p. 36) įvardija šias socialinių medijų rǔšis:

- tinklaraščiai;

- $\quad$ socialinių tinklų svetainès (Facebook, Twitter ir kt.);

- virtualūs socialiniai pasauliai (pvz., Second Life);

- virtualūs bendradarbiavimo projektai (Wikipedija);

- turinio dalijimosi bendruomenès (Youtube);

- virtualūs žaidimų pasauliai (World of Warcraft).

Internetas iki šiol dažnai suvokiamas kaip naujoji medija, arba terpè, kurioje susiklostė plačios atgalinio ryšio komunikuojant galimybès. Iki web 2.0 technologiniu priemonių paplitimo, dvikrypte komunikacija internete buvo gana ribota, taigi skelbiamas turinys priminè tradicinę žiniasklaidą. Redakcijos formavo turinị, skaitytojai skaitė. Supaprastejus technologinèms priemonèms, atsirado daugiau galimybių skaitytojui tiesiogiai dalyvauti savarankiškai kuriant turinį arba tiesiogiai reaguojant ị skaitomą turinị. Tokios medijos ịijo socialiniu mediju statusą. Mokslininkų teigimu, socialinès medijos veikia taikant plačiai prieinamas internetines publikavimo technologijas, kurios komunikaciją paverčia interaktyviais dialogais (Yu-Chen, Rong-An, Ming-Jin, 2013, p. 1). Ch. Wankel (2010, p. 112) nuomone, didžioji socialinių medijų vartotojų dalis yra eiliniai piliečiai. Autorius ịvardija kelias socialinių medijų naudojimo priežastis: saviraiškos ar kūrybingumo išraiškos priemonè, informacijos sklaida, diskusijos, tapatybès formavimas, poilsis ir pramoga. Remiantis J. Turow (2011 p. 495) mintimis, socialinès medijos tapo 
pagalbiniu įrankiu verslui, siekiančiam finansinès plètros išnaudojant platesnę socialinę komunikaciją naujujų medijų kanalais.

Visuomeneje ypač išpopuliarejo ir paplito socialinių tinklų svetainės (angl. Social Networking Sites, pvz., Facebook, Twitter, LinkedIn). 2014 metu pradžioje vien Facebook svetainejje registruota 1,11 bilijono vartotojų (Facebook statistic (...), 2013). Nusileidžianti socialinių tinklų svetainėms populiarumu, bet gana plačiai paplitusi kita socialinių medijų rūšis - tinklaraščiai (blogai, terminas kildinamas iš trumpinio anglų kalba web log - blog). 2012 metų Nielsen analitiniame tinklaraštyje paskelbta, kad 7 milijonai žmonių skelbia ịrašus tinklaraščiuose, dar 12 milijonų tinklaraščius rašo savo socialinių tinklų paskyrose. Ten pat demonstruojamas ir tarpusavyje susietos tinklaraščiu visumos (blogosferos) augimas: 2006 m. ją sudare 36 milijonai, 2011 m. - jau 181 milijonas, per metus iki 2012 metų blogosferos apimtis išaugo dar milijonu tinklaraštininkų (Nielsen, 2012).

Vienos populiariausių tinklaraščiu kūrimui skirtų interneto programinès įrangos svetainès „Wordpress“ statistika skelbia, kad nuo sistemos ịkūrimo 2006 m. iki 2014 m. kovo 1 d. ja naudojantis sukurti 76301435 tinklaraščiai. Sistema leidžia naudoti 120 kalbų ịrašus, tik 66 proc. tinklaraščiu yra anglų kalba (rusų - 1,1, švedų - 1, lietuvių kalba nepatenka ị populiariausių kalbų dešimtuką). Automatinė sistemos statistika registruoja maždaug 409 milijonus asmenų, kurie per mėnesị peržiūri 13,1 bilijono ịrašų (registruotų puslapių atvertimų). Sistemos vartotojų statistikos kreivè beveik tolygiai didèja (Wordpress.com stats, žiūrèta 201404 4). Minèti argumentai leidžia teigti, kad tinklaraščių medijos naudojimas, taikant laisvai prieinamas publikavimo technologijas, sparčiai plečiasi, o tai argumentai, pagrindžiantys tinklaraščio medijos, kaip tyrimo objekto, aktualumą.

\section{Tinklaraščių turinio ypatybės}

Medijų tyrejo A. Šumino (2012) teigimu, ,tinklaraščiai suvokiami kaip autentiškos ir neredaguojamos informacijos kanalas, kuriame įrašai pateikiami būtent tokia forma, kokia juos skelbia tinklaraštininkas, ir nèra niekieno daugiau redaguojami“ (Šuminas, 2012). Šiuo atžvilgiu tinklaraščiai skiriasi nuo oficialiosios spaudos, kurioje už skelbiamą turinị atsakinga redakcija, todèl prieš skelbiant ji viešai jis aprobuojamas. Būtent tuo tinklaraščiuose skelbiamas turinys yra ịdomus skaitytojams.

R. Miliūtė nurodo, kad pirmieji tinklaraščiai pasirodė 1994 m., vienam JAV internautui virtualioje erdveje ėmus skelbti kasdienes savo naujienas, pasakoti apie matytus filmus ir skaitytas knygas. „Ilgainiui šis naujienu pateikimo ir platinimo būdas labai išpopuliarejo ir net ėmè konkuruoti su populiariaja žiniasklaida“" (Mi- 
liūtè, 2008, p. 1). Tinklaraščiai pamažu nebeapsiribojo asmeninių užrašų ar pastebẻjimų skelbimu, jie ėmè skelbti ir visuomenei rūpimą informaciją.

TNS.lt atlikta $2011 \mathrm{~m}$. Lietuvos žiniasklaidos analizė aprèpia Nacionalinio skaitymo tyrimo rezultatus, bet tyrime nèra duomenų apie socialinių medijų (taip pat ir tinklaraščių) skaitymą. Tyrimo rezultatai atskleidè, kad apie 80 procentų 15-29 metų jaunimo naudojasi socialinėmis medijomis (Žiniasklaidos tyrimų apžvalga, 2012, p. 26). Tos pačios agentūros 2012 metų tyrimuose jau skiriami tinklaraščių turinio ir komentarų skaitymo rodikliai, duomenis priskiriant interneto vartotojų sričiai. Konstatuojamas Lietuvos interneto medijų vartotojų skaičiaus augimas, ypač vartojimo intensyvumo didejimas. Iš visų interneto vartotojų net 81 proc. šia medija naudojasi kasdien (iš viso Lietuvoje $2012 \mathrm{~m}$. internetu naudojosi 68 proc. gyventojų). Analizuojant internautų poreikius ir veiklą internete, skiriami du su tinklaraščių medija susiję faktai: net 53 procentai naršančiųų internete skaito komentarus (naujienų portaluose, forumuose, tinklaraščiuose); 38 procentai skaito tinklaraščius, forumus (Žiniasklaidos tyrimų apžvalga, 2013, p. 23-25).

\section{Tinklaraščių apibrèžimai, jų naudojimo ir tyrimų sritys}

Tinklaraščiai, kaip specifinè medija, kuriami ir naudojami ịvairias tikslais. Tai atskleidžia mokslininkų atliktų tyrimų, susijusių su tinklaraščių panaudojimu, sričių analizè. Analizè atlikta raktažodžio blog pagrindu atlikus paiešką socialinių mokslų duomenų bazeje EBSCO. M. Stafanone ir J. Chyng-Yang (2007) tyrimas skirtas tarpasmeninès komunikacijos raiškai pasitelkiant kompiuterius. Tyrimų rezultatai atskleide, kad tinklaraščiai, kaip socialinè medija, visuomeniškiems žmonèms gali padèti plèsti ir palaikyti socialinius ryšius (Stafanone, Chyng-Yang, 2007, p. 1). Edukologai tinklaraščius naudoja naujosiomis technologijomis pagrịstas medijas pritaikydami mokymosi tikslams. C. Mollie aprašo tinklaraščiu panaudojimo galimybes mokymo procese, pateikia mokymo proceso valdymo, bendradarbiavimo kuriant ịvairaus pobūdžio tekstus, diskusijų puoselëjimo idejjų (Millie, 2006, p. 1). Tyrejų grupė analizavo, kaip galima organizuoti studentų savarankišką mokymąsi naudojant tinklaraščių kūrimą (Marques, Krejci ir kt., 2013, p. 395). Mokslininkai Ch. Yu-Chen, S. Rong-An ir L. Ming-Jin tinklaraščius analizavo iš turizmo vadybos perspektyvų, aiškindamiesi, kaip šiose medijose skelbiama informacija apie turistinius objektus daro įtaką potencialių turistų elgesiui, apsisprendžiant dẻl maršruto (Yu-Chen Chen, Rong-An, Ming-Jin, 2013). Psichologai tiria, kaip tinklaraščiuose išryškèja jų autorių ir skaitytojų jausminè komunikacija (Brook, 2012, p. 1607). Nemažai tyrimų susiję su tinklaraščių reikšme politinëje komunikacijoje. Politinei komunikacijai skirtas vienas iš nedaugelio mokslinių 
straipsnių lietuvių kalba, susijusių su tinklaraščio medijos panaudojimu (Šuminas, 2012). E. Jasutienè ir V. Dagienė tinklaraščius naudoja informacinių technologiju kompetencijų ugdymo analizès kontekste (Jasutienè, Dagienè, 2007). R. Miliūtė tinklaraščius analizavo kalbotyros aspektu (Miliūtè, 2008).

İvairus tinklaraščio medijos panaudojimas pagrindžia medijų teoretiko H. Winklerio medijų pamatinị apibrèžimą: „Medijos yra visuomeninio sąryšio mašinos“, suteikiančios pranešimui specifinę formą (Medijų kultūros balsai, 2009, p. 190). Akivaizdi šio tipo medijų plètra vis labiau ją paverčia „nematoma“, naudojimasis ja vis platesniam visuomenès ratui tampa savaime suprantamu reiškiniu.

\subsection{Apibrèžimai}

Medijas analizuojantys autoriai susiduria su vieningo medijų sąvokos apibrèžimo sunkumais. Dažniausiai medijos apibrěžiamos jų vartojimo kontekste, nusakant medijų srities ribas ir lyginant su kitomis visuomeninès sąveikos formomis.

J. Turow, analizuodamas medijų ir masinès komunikacijos aspektus, tinklaraščius apibrèžia kaip žurnalistines interneto (angl. websites) ar nuomonių (angl. opinion sites) svetaines, kur rašoma periodinio leidinio ịrašų stiliumi, dažnai atvirkščia chronologinei seka. Kaip labiausiai paplitusius JAV jis mini politinių nuomonių ir įžymių asmenų tinklaraščius. Autorius pabrèžia, kad tinklaraščiai papildo internetinio leidinio struktūrą. Jie būdingi popierinio laikraščio internetinei versijai, naudojami, kaip rinkodaros priemonè, kviečianti skaitytojus dialogui. J. Turowo teigimu, tinklaraščiai papildo popierinès versijos naujienas, čia galima plačiau atskleisti ịvykių aplinkybes, ịvairias nuomones ir tai sukelia tam tikrą skaitytojų reakciją (Turow, 2011, p. 48).

B. Gunterio teigimu, tinklaraštis yra interneto svetainè, kuriai būdingas asmeniškumo aspektas, kitaip tariant, jų kūrèjai tinklaraščius, kaip interneto svetaines, naudoja tam, kad išsakytų asmenini požiūrị ar pasvarstytų apie įvairius ịvykius, problemas (Gunter, 2009, p. 120).

E. Jasutienè ir V. Dagienè, analizuodamos informacinių technologijų kompetencijų ugdymą, tinklaraščius apibūdina kaip „lengvai visuomenei prieinamus ir reguliariai atnaujinamus tinklinius žurnalus, kuriuose tekstas ir vaizdiniai elementai pateikiami tam tikra chronologine tvarka" (Jasutienè, Dagienè, 2007, p. 40).

R. Thornburgo nuomone, tinklaraštis yra tam tikra pasakojimo kūrimo (literatūros) forma. Kaip apverstos piramidès principas ar haiku, taip ir tinklaraštis yra tarsi nustatytos formos taisyklès, kurios gali būti pritaikytos bet kokiam turiniui ar tikslui (Thornburg, 2010, p. 278). Ž. Pečiulis interneto tinklaraščius laiko socializacijos, savęs kūrimo ir ịtvirtinimo priemone. Jis pabrèžia, kad tinklaraščio 
rašymas skatina žmones komunikuoti. Nuolatinis tinklaraščio atnaujinimas skatina jị rašantiji gilinti tam tikrus ịnūdžius, domètis ne tik ta tema, apie kurią rašoma, bet ir plačiau (Pečiulis, 2009, p. 43).

A. Šuminas tinklaraščių medijos panaudojimą skirsto ị tris kategorijas: 1) turinio ašis (asmeninis ar konkrečiai temai skirtas tinklaraštis); 2) krypties ašis (monologas - dialogas) ir 3) stilistikos ašis (intymiai subjektyvus - siekiantis objektyvumo) (Šuminas, 2012).

Tinklaraščiu medijos panaudojimą tiria daugelio sričių mokslininkai: psichologai, komunikacijos specialistai, politikos mokslų atstovai, kalbininkai, edukologai, vadybininkai, žurnalistai. Apibūdindami tinklaraščius, autoriai pabrèžia šias medijų savybes: 1) turinio periodiškumas; 2) chronologinė seka; 3) asmeniškumas, kuriant turinị; 4) turinio įvairovė; 5) lanksčiai įvairiam turiniui pritaikoma forma, skirta saviraiškai ir socialinei komunikacijai; 6) turinio skelbejjų ir auditorijos sąveikos svarba. Apibrèžimuose pastebima sampratų ịvairovè pasireiškia ir autorių pateikiamose tinklaraščiu klasifikavimo sistemose.

\subsection{Tinklaraščių klasifikavimas}

Kompiuterinès informatikos specialistė R. Blood tinklaraščius skirsto ị:

- Dienoraščius - tai svetainès, primenančios sutrumpintos formos žurnalus. Tinklaraščio tema - autoriaus kasdienis gyvenimas. Publikacijų tekstus papildo nuorodos ị kitas naujienas, ịvairaus turinio publikacijas, kurios papildo esminę informaciją.

- Užrašus - asmeniniai arba dėmesį ị išorinị pasaulį sutelkiantys užrašai nuo dienoraščiu skiriasi didesnėmis kryptingai formuojamo turinio dalimis. Asmeniniai ịrašai kartais ịgauna istorijos ar pasakojimo formą. Kartais ịrašai tampa vieša kontempliacijos vieta, čia gali būti ịtraukiamos nuorodos i pirminę apmąstymus sukèlusią informaciją, bet patys tinklaraštininkų apmąstymai išlieka teksto pagrindu. Paprastai užrašų tipo tinklaraščiai pasižymi kokybiškesniu teksto redagavimu. Užrašų tipo tinklaraščiai dėmesi sutelkia ties vidiniu autoriaus pasauliu, jo reakcijomis ị supantị pasaulị. Teksto nuorodos suteikia papildomos informacijos.

- Filtrus - interneto svetainè, kurios informacija orientuota ị nuorodas. Tinklarašti filtrą paprastai veda užkietèjęs internautas, gerai žinantis technologinę medijos valdymo pusę. Asmeninè informacija šio tipo svetainèse nebūtina, čia autorius nori parodyti visą pasaulị, taip atskleisdamas kitų sukurtą turinị. Taip autorius tarsi atskleidžia savo asmenybę - per išorinius veiksnius, netiesiogiai, pasitelkdamas nuorodas, kaip komunikacijos ženklus. Kai kurie filtrų stiliaus tinklaraščiai orientuoti ị konkrečios temos 
tęstinị atskleidimą, tokio tinklaraščio tikslas - pateikti visas galimas temos naujienas (Blood, 2002, p. 6).

R. Blood tinklaraščius klasifikuoja, atsižvelgdama ị juose pateikiamų įrašų turinį, kaip skiriamaji požymị nurodydama teksto stilių ir skelbiamos informacijos asmeniškumo pobūdį. Visose išskiriamose kategorijose pabrēžiamas asmenybės atskleidimas, naudojant skirtingas raiškos priemones.

Informacijos valdymo požiūriu bibliotekininkas M. Sauers skiria šias tinklaraščių kategorijas:

- asmeniniai: kuriami asmeniniais tikslais, publikuojant autentiškas mintis, kurios susijusios su asmenine patirtimi ar profesiniu gyvenimu;

- teminiai: vedami vieno asmens arba grupés ir orientuoti $\mathfrak{i}$ tam tikrą temą (pomėgius, politiką, gyvūnus ir t. t.);

- organizacijų: reprezentuoja nuomones, pažiūras ir įvykius, kurie susiję su organizacija (kelionių agentūrų, bibliotekų ar kitų institucijų tinklaraščiai). Šiuos tinklaraščius, autoriaus nuomone, galima pavadinti viena iš institucijos rinkodaros priemonių. Pastebima, kad ši tinklaraščiu tipą perima ir asmenybès, norinčios viešinti savo nuomones, pažiūras, skleisti informaciją apie svarbius įvykius, kurie susiję su jų asmeniu. Ypač tai paplitę tarp politikų. Tokio pobūdžio tinklaraščiai tampa savotišku CV, asmeninès reputacijos kūrimo priemone (Sauers, 2010, p. 1-3).

Tinklaraščių klasifikavimo pagrindu M. Sauers pasirinko turinio kūrimo tikslą ir pobūdị, atskirdamas asmeninius (patirties) dienoraščiu tipo tinklaraščius nuo tų, kurie nukreipti atskleisti konkrečią temą. Kaip atskira grupe išskiriami veiklą reprezentuojantys tinklaraščiai, skirti kurti ịvaizdị.

Žurnalistikos mokslininkas T. Thornburg tinklaraščius skirsto atsižvelgdamas ị tai, kokiai auditorijai jie skirti, kokio tikslo siekiama jų turiniu. Jis skiria keturis pagrindinius tinklaraščių tipus:

1. Asmeniniai tinklaraščiai (dienoraščiai), skirti šeimos nariams ar nedidelei skaitytojų grupei. Tai gausiausia tinklaraščių grupè.

2. Nuomonių tinklaraščiai, atstovaujantys tam tikrai nuomonei politikoje, aptariant ịvykius ir pan. Paprastai tokius tinklaraščius rašo vienas asmuo, tekstai orientuoti ị kuo platesnę skaitytojų, kurie dažniausiai tinklaraščio autoriaus asmeniškai nepažįsta, auditoriją.

3. Smūginiai (ar patruliuojantys, greitos reakcijos (angl.) Beat) tinklaraščiai dažniausiai rašomi profesionalaus reporterio, kuris laikosi žurnalistikos etikos normų ir kokybės standartų ir siekia plačiai bei išsamiai atskleisti 
vieną kurią temą. Tinklaraštis rašomas vieno asmens arba veiklą koordinuoja vienas asmuo, o informaciją pateikia keletas reporterių. Tinklaraščio turinys orientuotas i plačią auditoriją, skaitytojai nei tinklaraščio autoriaus, nei reporterių dažniausiai asmeniškai nepažįsta.

4. Naujienų tinklaraščius veda vienas ar keletas profesionalių reporterių, kurie orientuoti ị greitą naujienų pateikimą skaitytojams (plačiajai auditorijai, visuomenei) (Thornburg, 2010, p. 279).

Visose pristatytose tinklaraščių klasifikacijose autoriai kaip atskirą kategoriją išskiria asmeninius dienoraščius, kurie pasižymi autentiškumu ir skirti asmenybei atsiskleisti. Tai tinklaraščio medijos naudojimo ištakos, šios tendencijos išlieka aktualios. Kitos kategorijos skiriasi atsižvelgiant ị mokslininkų pasirinktus konkrečiai tinklaraščių taikymo sričiai būdingus klasifikavimo kriterijus.

\subsection{Išskirtiniai tinklaraščių bruožai}

Autoriai, analizuojantys tinklaraščių medijos specifiką, skiria ir šiai medijai būdingus bruožus. Juos M. P. Sauers taip ịvardija:

- Savalaikiškumas: jie atnaujinami daug dažniau nei dauguma kitų svetainių. Skirtingai nei tradicinèse medijose, tinklaraščiuose pateikiamai informacijai nekeliami aukšti kokybės reikalavimai, čia informacija pateikiama dar ,žalia“, tai leidžia greičiau ją paskleisti. Kadangi publikuojami greitai, tinklaraščiai tampa pirmuoju informacijos šaltiniu, informacijai pasitvirtinus, ją perima dienraščiai ar rimtesni portalai.

- Drąsa: tinklaraščio kūrejjas turi asmeninę nuomonę, ją savo darbuose išreiškia drąsiai ir nedviprasmiškai. Tinklaraščių autorių neriboja jokie suvaržymai: jie gali rašyti bet kuriomis temomis, čia nèra griežtų objektyvumo ir nešališkumo reikalavimų (kaip žurnalistikoje). Tinklaraščio autorius kuria savas taisykles, pagal kurias rašo savo internetinị dienoraštic.

- Pasiekiamumas: tas, kuris kuria tinklaraštį, turi iš anksto pagalvoti apie jo optimalų pasiekiamumą, nes tam jis skirtas. Jei prieiga prie tinklaraščio bus apribota ar sudetinga, jis neatliks savo funkcijos kaip socialinè medija ir sunyks (arba veiks kaip asmeniniai užrašai) (Sauers, 2010, p. 7).

Pabrèždamas prieigos svarbą, kaip esmini tinklaraščiu medijos bruožą M. P. Sauers išskiria dialoga tarp autoriaus ir skaitytojų. Tinklaraščio autoriaus triūsas nesibaigia teksto paskelbimu, iš tiesų jis tuo tik prasideda, nes tikras darbas vyksta sukeliant atsakomają skaitytojų reakciją (komentarus) ir atsakant ị skaitytojų pastebejjimus, klausimus (Sauers, 2010, p. 167). Kaip išskirtinį tinklaraščio 
bruožą autoriai nurodo atvirkščią chronologinei tekstų paskelbimo seką, kai aiškiai nustatoma data ir naujausi įrašai visada pasirodo ekrano viršuje. Tinklaraščio sukūrimo technologijos leidžia lengvai nustatyti turinio archyvavimo paslaugą, kas padeda lengvai surasti anksčiau įkeltus įrašus.

E. Jasutienè ir V. Dagienè kaip išskirtinị tinklaraščio bruožą mini dizaino kūrimo patogumą: keisti dizainą tinklaraščio medijoje nesudètinga, tai gali atlikti pats autorius bet kuriuo metu. Todèl naudojamas tinklaraštis yra dinamiškas (Jasutienè, Dagienè, 2007, p. 5).

T. Thornburg nurodo, kad išskirtinis tinklaraščių bruožas yra jų ,,standartizuotos formos paprastumas, susijęs su paprasta kompiuterine ịranga, kuriai valdyti nereikia turèti išskirtinių programavimo žinių ir igūdžių“" (Thornburg, 2010, p. 278). „Susikūręs tinklaraštị, kiekvienas gali tapti spaudos priemonès savininku“ (Thornburg, 2010, p. 279). Šia mintimi žurnalistikos mokslininkas ịvardija žurnalistikoje svarbų „tarpininko leidybos procese nebuvimo“ aspektą, igalinantị patị tinklaraštininką skelbti kitiems leidejjams galimai nepriimtinus faktus, duomenis, įžvalgas, sudarantị sąlygas drąsiai reikštis visuomenèje.

T. Thornburg pateikia rekomendacijų tinklaraščio turinio kūrejjams:

1. Tinklaraščius sudaro ịvairios apimties ịrašai (angl. posts). Kiekvienas ịrašas skiriamas vienam ịvykiui ar temai. İrašai tinklaraščiuose neturi būti pateikti ,apverstos piramidès“ principu.

2. Irašai ịkeliami ị tinklaraštị horizontaliai slenkant žemyn, naujausi ịrašai atsiranda ekrano viršuje.

3. Profesionaliai vedamų naujienų tinklaraščiu įrašai beveik visada skiriami vienai temai. Paprastai tokių tinklaraščiu įrašai vadinami „smūgiais“ (angl. beats).

4. Daugelis tinklaraštininkų kviečia skaitytojus komentuoti ịrašus.

5. Daugelị tinklaraščiu veda vienas autorius, bet yra ir tokių, kuriuos veda grupe žmonių ar vienas asmuo turi keletą reporterių.

6. Dauguma tinklaraštininkų taiko nuorodų ị pirminius šaltinius sistemą, taip tarsi parodydami savo veiklos skaidrumą (Thornburg, 2010, p. 279).

Šios rekomendacijos apibrèžia tinklaraščio panaudojimo žurnalistikoje ribas, nurodo šiai medijai būdingus turinio kūrimo bruožus.

Medijų teoretikas Geert Lovink kritiškai vertina tinklaraštinimo veiklą, vadindamas ją ,nihilistiniu impulsu“. Pripažindamas tinklaraščių įtaką kultūrai, autorius pabrèžia tinklaraštininkų ,kultūrinį nihilizmą, atvirai kvestionuojantị masinių žiniasklaidos priemonių hegemoniją. Tinklaraščiai anuliuoja centralizuotas prasmių struktūras ir sutelkia dèmesị ị asmenines patirtis“ (Medijų kultūros balsai, 2009, p. 253). 
Išskirdami tinklaraščio bruožus, autoriai ịvardija šiai medijai būdingas savybes, kurios lemia platų jos panaudojimą. Medijos panaudojimo plètrą igalina supaprastintos kompiuterinio programavimo galimybès. Tai šios medijos naudotojams suteikia galimybę tapti nepriklausomu leidèju ir drąsiai bei greitai skelbti informaciją. Leidybos dizaino kaitos lankstumas sudaro sąlygas sukurtos medijos dinamiškumui. Chronologine įrašu seka, archyvavimo galimybe ir patogus informacijos paieškos įrankių sistemos sukūrimas tinklaraščio skaitytojams leidžia ịveikti laiko ribas ir lengvai atrasti anksčiau skelbtą turinị. Šiai medijai būdingos kūrejo asmeninio kūrybiškumo raiškos neriboja griežti objektyvumo reikalavimai. Akcentuojamas dialogo siekis, kuriuo didinamas turinio skaidrumas, siekiama atgalinio ryšio.

\section{Išvados}

Neilga tinklaraščio medijos atsiradimo ir gyvavimo istorija ir įvykęs šios medijos naudojimo statistikos šuolis rodo mediją tampant realia, nematoma pasaulio pažinimo dalimi. Teoriniai analizuojamos medijos apibrěžimai nevienareikšmiški, tačiau jie išskiria konkrečiai medijai būdingas savybes, kurios lemia jos populiarumą ir išskirtinumą. Tai pasireiškia esminiais tinklaraščio medijos bruožais, kurie ir lemia plačias jo panaudojimo galimybes. Skaitytojus tinklaraščiai domina skelbiamo turinio autentiškumu, drąsa ir tiesioginio atgalinio ryšio paprastumu. Kuriantiesiems tinklaraščius ši medija patraukli dèl nesudètingų kompiuterinio programavimo galimybių, galimybès tiesiogiai pasiekti auditoriją ir su tuo susijusios saviraiškos ir / ar profesionalumo siekio galimybès.

Gauta 20140402

Pasirašyta spaudai 20140701

\section{Literatūra}

Ahlqvist, T., Back, A., Halonen, M., Heinonen, S. (2008). Social Media Roudmaps: Exploring the future triggered by social media (interaktyvus). Helsinki, Finland: Edita Prima Oy, VTT. ISBN 978-951-38-7246-5. Prieiga internete: <http://www.vtt.fi/inf/pdf/tiedotteet/2008/T2454.pdf> [žiūrèta 201311 15].

Blood, R. (2002). The Weblog Handbook. Practical Advice on creating Maintaining Your Blog. Cambridge: Basic books, 144 p. ISBN 10:073820756X.

Brook, B. (2012). Disagreement and agreements in personal/diary blogs: A closer look at responsiveness. Journal of Pragmatics, vol. 44, issue 12, September: 1607-1622.

Craig, B., Schaller, R. C. (2010). Writing for the Internet. A Guide to Real Communication Virtual Space. Texas: Greenwood press, 219 p. ISBN 978-0313376948.

Craig, D. A. (2011). Exellence in Online Journalism. Exploring Current Practices in an Evolving Environment. Los Angeles, vol. 10, 180 p. ISBN 978-1-4129-7009-9. 


\section{TINKLARAŠČIO MEDIJOS ESMINIAI BRUOŽAI IR PANAUDOJIMO GALIMYBĖS}

Dewney, A., Ride, P. (2006). New Media Handbook (Media practice). London and New York: Routledge, 352 p. ISBN-10:0415307120.

Facebook statistic - statistic Brain. (2013). Statistic Brain Research Institute, publishing as Statistic Brain. Prieiga internete: http://www.statisticbrain.com/URL OF PAGE BEING CITED [žiūrèta 2014-03-01].

Geert, L. (2009). Tinklaraščiai - nihilistinis impulsas. Medijų kultūros balsai: teorijos ir praktikos. Vilnius: Mene, p. $253-266$.

Graham, J. (2010). The complete guide to social media (interaktyvus). (Didžioji Britanija): Amazon.com. Prieiga internete: <http://www.grahamjones.co.uk/category/encyclopaedia/social-media-encyclopaedia> [žiūrèta $20131115]$.

Gunter, B. (2009). Blogging - private become public and public becomes personalized. Aslib Proceedings: News Information Perspectives (interaktyvus), vol. 61, issue 2, p. 120-126. Prieiga internete: <http://www.emeraldinsight.com/bibliographic_databases.htm?id=1792706\&show=abstract> [žiūrèta 20130720 ].

Yu-Chen, Ch., Rong-An, S., Ming-Jin, L. (2013). The effects of perceived relevance of travel blogs' content on the behavioral intention to visit a tourist destination [interaktyvus]. Computers in Human Behavior, vol. 29. Prieiga internete: <http://www.sciencedirect.com/science/article/pii/S0747563213001702> [žiūrèta $20130720]$.

Jasutienè, E., Dagienė, V. (2007). Skaitmeniniai aplankai ir tinklaraščiai vertinant IKT kompetenciją. Informacijos mokslai (interaktyvus), vol. 42-43. Prieiga internete: <http://www.ims.mii.lt/ims/Jasutiene_Dagiene. pdf> [žiūrèta 20121115$]$.

Lietuvos web 2.0 apžvalga: tinklaraštis. Mariaus Kuitniausko tinklaraštis (interaktyvus). Prieiga internete: $<$ http://blog.lrytas.lt/web20/tag/blogai/> [žiūrèta 201307 20].

Marques, A. M., Krejci, R., Siqueira, S. W. M., Pimentel, M., Braz, M. H. (2013). Structuring the discourse on Social networks for learning: Case studies on blogs and microblogs. Computers in Human Behavior, vol. 29 (2): 395-400.

Mediju kultūros balsai: teorijos ir praktikos. (2009). Sudarytojas V. Michelkevičius. Vilnius: MENE, 291 p. ISBN 978-9955-834-02-1.

Miliūtė, R. (2008). Tinklaraščių kalbos vieta dabartinès lietuvių kalbos vartosenos schemoje. Lietuviu kalba. Mokslo žurnalas (interaktyvus), nr. 2. Prieiga internete: $<$ http://www.lietuviukalba.lt/index.php?id=98> [̌iūrèta 201311 15].

Mollie, C. (2006). Using Blogs to Integrate Technology in the Classroom. Teaching Today, October (interaktyvus). Prieiga internete: <http://www.glencoe.com/sec/teachingtoday/educationupclose.phtml/47>.

Nevinskaitè, L. (2011). Šiuolaikinès medijos ir masinės komunikacijos teorijos. Vilnius: Petro ofsetas, 120 p. ISBN 978-609-420-203-2.

Nielsen: komunikacijos internete organizavimo tinklaraštis. (2012). Worldwide organisation: Nielsen family (interaktyvus). Prieiga internete: <http:/www.nielsen.com/us/en/newswire/2012/buzz-in-the-blogosphere-millions-more-bloggers-and-blog-readers.html $>$.

Pečiulis, Ž. (2009). Žiniasklaida ir žurnalistika daugiaterpès raiškos eroje. Informacijos mokslai, vol. 51: $37-53$.

Sauers, M. P. (2010). Blogging and RSS: a librarian's guide (interaktyvus). FreeBooksspot; Information today inc., 336 p. ISBN 978-1-57387-399-4. Prieiga internete: <http://www.freebookspot.es/Comments. aspx?Element_ID=286364> [žiūrèta 201307 20].

Stafanone, M. A., Chyng-Yang, J. (2007). Writing for Friends and Family: The Interpersonal Nature of Blogs. Journal of Computer-Mediated Communication (interaktyvus), vol. 13(1), article 7. Prieiga internete: $<$ http:// jcmc.indiana.edu/vol13/issue1/stefanone.html> [žiūrèta 201307 20].

Šuminas, A. (2012). Tinklaraščiai, kaip politinės komunikacijos ịrankis: Lietuvos Respublikos Seimo narių atvejis. Parlamento studijos, nr. 13. Prieiga internete: http://www.parlamentostudijos.lt/Nr13/13_komunikacija_1.htm

Thornburg, R. M. (2010). Producing Online News: Digital Skills, Stronger Stories. Oslo: CQ Press College, 350 p. ISBN 978-1604269963. 
Turow, J. (2011). Media today. An Introduction to Mass Communication. 4th ed. New York and London: Routlege, 610 p. ISBN 13:987-0-415-87607-0.

Wankel, Ch. (2010). Teaching arts and science with the new social media. Bingley: Emerald pubishing, $405 \mathrm{p}$. ISBN 10:0857247816.

Wordpress.com. (2013). Statistikos puslapis (interaktyvus). Prieiga internete: $<$ http://en.wordpress.com/stats/> [Žiūrèta 201307 20].

Žiniasklaidos tyrimu apžvalga: 2011. (2012). (Interaktyvus). Vilnius: TNS. Prieiga internete: <http://www.tns. 1t/data/files/Metines_apzvalgos/Ziniasklaidos\%20tyrimu\%20apzvalga\%202011.pdf> [žiūrèta 201307 20].

Žiniasklaidos tyrimu apžvalga: 2012. (2013). (Interaktyvus). Vilnius: TNS. Prieiga internete: http://www.tns.lt/ data/files/Metines_apzvalgos/Ziniasklaidos\%20tyrimu\%20apzvalga\%202012.pdf [žiūrèta 201404 07].

\section{ESSENTIAL FEATURES AND USABILITY OF BLOG MEDIA}

\section{Daiva Janavičienė}

Summary

Nowadays social media take more and more of Internet space and it become a very important mean to disseminate information, express oneself and communicate. Social media have appeared and spread when web 2.0 possibilities have come into force on the Internet and lead to a simplified mutual communication. The aim of this analysis is to overview the blog use possibilities after having made an analysis of the fundamental blog media features. The object of the given research - the blog media. The research is being conducted using theoretical induction, deduction and analogy research methods.

The cognition of information that we are surrounded by takes place through the information exchange. Information transmission means or channels which it is transmitted through are called media (in Latin "media" mean "the middle"). Social media theories are a phenomenon of the second half of the 20th century. The latter phenomenon takes only a short historical period. Simultaneously, according to V. Michelkevicius, "media landscape is changing faster than the theories about them" (Medijų kultūros balsai [= Media surveys], 2009, p. IV). In the emerged arena of the competitive battle of new technologies, some technologies disappear without even trying to fight, while others pervade and come into force. According to a lot of researchers, social media indicate interaction among people across the Internet blogs and virtual communities where they create, share and exchange information through communication.

Social Networking Sites have especially become popular and pervaded in a society (e.g. Facebook, Twitter, Linkedin). At the beginning of 20141.11 bln users 
were registered on a single Facebook Networking Site (Facebook statistic, 2013). Another social media type which is not so popular as Social Networking Sites but rather widely spread - the blogs (the term originated from the English phrase "web $\log$ " as its abbreviation). In the analytical Nielsen blog of 2012 the fact that $7 \mathrm{mln}$ people publish their posts in the blogs and $12 \mathrm{mln}$ people write their own blogs in their social networking accounts was announced. The growth of interconnected blog sets (blogsphere) is also demonstrated there - in 2006 it consisted of $36 \mathrm{mln}$, in 2011 - already $181 \mathrm{mln}$, in a year until 2012 the volume of the blogsphere has increased by $19 \mathrm{mln}$ more bloggers (Nielsen, 2012, accessed $4^{\text {th }}$ of March, 2014)

The TNS.lt analysis conducted on Lithuanian media include National reading research results, however, there are no data about social media (including and blogs) reading. The same agency in its research of 2012 already distinguished the rates of social media content and comment reading, assigning data to the Internet user sphere. The growth of the number of Lithuanian Internet media users, especially, the growth of the use intensity, is stated. Out of all Internet users even 81 $\%$ uses these media daily (in total in $201268 \%$ of the inhabitants of Lithuania were using the Internet). Analyzing the needs and the work of the bloggers on the Internet, 2 facts related to the blog media are distinguished - even $53 \%$ of those searching the Internet read comments (in the news sites, forums, blogs). $38 \%$ read blogs and forums (Žiniasklaidos tyrimų apžvalga [= Media surveys], 2013, p. 23-25).

The search in the database of social science that has been made basing on a keyword "blog" has indicated the range of researches which were conducted on a basis of the blog analysis. The blogs are being analyzed from the interpersonal point of view (Stafanone ir Chyng-Yang, 2007, p. 1) as an educational means (Millie, 2006, p.1; Marques, Krejci ir kt., 2013, p. 395], from the perspective of tourism management (Yu-Chen Chen, Rong-An ir Ming-Jin, 2013), even from the perspective of emotional communication expression (Brook, 2012, p. 1607). Perhaps the blogs are most widely used in a political communication, it is reflected and in the article written in Lithuanian which is dedicated to the analysis of blogs (Šuminas, 2012). In the scientific publications written in Lithuanian language the blogs were analyzed in a sense of information competence education (Jasutienè, Dagienè, 2007) and linguistics (Miliūtè, 2008).

The blog classifications by R. Blood, the specialist of computer Information Sciences (Blood, 2002, p. 6), M. Sauers, the librarian (Sauers, 2010, p. 1-3) and T. Thornburg, the scientist of journalism (Thornburg, 2010, p. 279), are introduced in the article. The features which media are characterized with and which are named by M. Sauers (Sauers, 2010, p. 7) and T. Thornburg (Thornburg, 2010, p. 278); E. Jasutiene, V. Dagiene (Jasutienè, Dagiené, 2007, p. 5) and G. Lovink 
(Medijų kultūros balsai [=Media culture votes], 2009, p. 253), are contrasted. The latter authors name the media-specific-features which make an impact on the media use itself. The simplified computer programming possibilities enable the media use expansion. These media provide the users with the possibility to become independent publishers and publish information boldly and quickly. The publishing design change flexibility allow the dynamism of the created media. A chronological sequence of posts, the archiving possibility and a comfortable information search tool system composition allow the readers of the blog to save their time and easily find the content of the post which was published earlier. The possible expression of personal creativity of the creator specific to these media is not limited by strict objectivity requirements. The focus is the seek for a dialogue which expands the seek for the content clarity and feedback.

A short history of the blog media emergence and lifetime and the statistical leap of these media use indicate the media to become a real and invisible part of the world cognition. Theoretical definitions of the analyzed media are not unanimous, however, the features specific to these specific media and determining its exclusiveness and popularity are distinguished in them. It manifests through fundamental blog media features which determine the wide opportunities to use them. The readers are interested in the blogs because of their authenticity, braveness and simplicity for the direct feedback. For those who create blogs, this media is attractive due to its non-complex programming possibilities which provide them with the direct access to audience and the possibility for self-expression and / or for a seek for professionalism this way. 